\title{
Strategi Komunikasi Humas Satuan Polisi Pamong Praja Jambi Menjaga Ketertiban Pedagang Kaki Lima
}

\author{
Sartika, Pirhat abbas, Nurhasanah, Mardalina, Muhsin Ruslan \\ Email: mardalina@uinjambi.ac.id
}

\begin{abstract}
Abstrak: Penelitian ini dilatarbelakangi oleh kurangnya kesadaran pedagang kaki lima untuk menjaga ketertiban, masih ada pedagang kaki lima Jalan Letjen Haryono Telanipura yang berjualan tidak sesuai dengan Peraturan mereka berjualan pada jam kerja antara pukul 06.00 s/d 16.00 WIB. Sebagai aparat Penegak Peraturan Daerah Satuan Polisi Pamong Praja dalam penyampaian informasi di bantu Humas dalam menyampaikannya. Dari persoalan tersebut mendorong penulis untuk melakukan penelitian untuk mengetahui Strategi KomunikasiHumas Satuan Polisi Pamong Praja dalam Menjaga Ketertiban Pedagang Kaki Lima Pendekatan Penelitian yang penulis gunakan adalah penelitian kualitatif. untuk menjelaskan apa yang terjadi secara lengkap, dengan menggunakan data primer dan skunder sebagai jenis data dan sumber data yang diperoleh melalui Humas (Kepala Satuan, Kasubag Umum dan Kepegawaian, Seksi Ketertiban Umum) dan Pedagang Kaki Lima di Kec. Telanaipura. Teknik pengumpulan data dilakukan melalui observasi, wawancara dan juga dokumentasi. Dari pengumpulan data tersebut dilakukan tiga analisis data yang berupa analisis data, yang berupa reduksi data dan dan vertifikasi data. Hasil penulis temukan bahwa Strategi Komunikasi Humas menjaga Ketertiban Pedagang Kaki Lima yaitu: komunikasi persuasif, komunikasi melalui surat dan komunikasi sosialisasi.
\end{abstract}

Kata-kata kunci: strategi komunikasi, humas, Satuan Polisi Pamong Praja.

\section{A. Pendahuluan}

Manusia pada dasarnya adalah makhluk sosial, manusia secara alami selalu membutuhkan hubungan atau komunikasi dengan manusia yang lain, manusia secara alami mempunyai dorongan untuk berhubungan dengan manusia lain. Disamping itu manusia juga mempunyai dorongan-dorongan lain seperti dorongan ingin mengaktualisasi diri dan lain sebagainya. Dorongan-dorongan tersebut akan dapat dipenuhi dengan mengadakan komunikasi dengan sesamanya. Melalui komunikasi sesorang dapat menyampaikan informasi, ide 
atau pemikiran, pengetahuan, konsep dan lain-lain kepada orang lain secara timbal balik, baik secara penyampaian maupun sacara penerima komunikasi. Dengan komunikasi manusia dapat berkembang dan melangsungkan kehidupan bermasyarakat. ${ }^{1}$

Dalam melaksanakan perannya (komunikasi) menggunakan perangkat dan piranti keras ada dalam tubuh organisasi maupun yang terdapat di dalam masyarakat. sadar bahwa kegiatan komunikasi adalah kegiatan yang dinamis dan banyak aspek teknis, psikologis, maupun politis dan sosiologis maka humas harus bersikap kreatif, ulet, pantang menyerah, dan selalu terbuka untuk selalu menyehatkan mutu profesi pengetahuan serta dedikasi. Atas dasar keyakinan bahwa kegiatan komunikasi harus dilakukan secara terpadu bersama-sama maka harus menaati dan mengindahkan peraturan dan perundangan yang ada dan berlaku (menaati aturan permainan). ${ }^{2}$

Menaati aturan adalah sikap yang harus dimiliki oleh setiap umat islam untuk mematuhi apa yang menjadi aturan. Allah SWT berfirman QS An-Nur ayat 54:

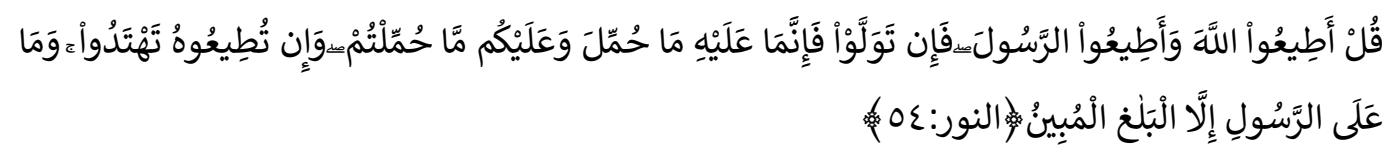

"Katakanlah: "Taat kepada Allah dan taatlah kepada rasul; dan jika kamu berpaling maka sesungguhnya kewajiban rasul itu adalah apa yang dibebankan kepadanya, dan kewajiban kamu sekalian adalah semata-mata apa yang dibebankan kepadamu. Dan jika kamu taat kepadanya, niscaya kamu mendapat petunjuk. Dan tidak lain kewajiban rasul itu melainkan menyampaikan (amanat Allah) dengan terang". (QS.An-Nur ayat 54). ${ }^{3}$

Penyelenggaraan ketentraman dan ketertiban merupakan urusan wajib yang harus diselenggarakan oleh pemerintah daerah.Untuk membantu kepala daerah dalam melaksanakan urusan wajib tersebut maka setiap daerah otonom

\footnotetext{
${ }^{1}$ Bimo Walgito, Psikologi Sosial, ( Yogyakarta: CV.Andi Offset, 2003), 75

${ }^{2}$ Widjaja, Komunikasi dan Hubungan Masyarakat, (Jakarta: PT.Bumi Aksara,2008), 52-53

${ }^{3}$ Tim Penterjemah dan Penafsir al-Qur'an, Al-Qur'an dan Terjemahannya (Jakarta: Departemen Agama RI.,2006),357.
} 
mempunyai unsur pelaksana pemerintah daerah, salah satunya adalah satuan polisi pamong praja yang merupakan lembaga teknis daerah dan pembentukannya berdasarkan Peraturan Pemerintah No 6 Tahun 2010. ${ }^{4}$

Fungsi Humas dalam menyelenggarakan komunikasi timbal balik dua arah antara organisasi dan badan yang diwakilinya dengan publik sebagai sasaran pada akhirnya dapat menentukan sukses atau tidaknya tujuan yang hendak dicapai. ${ }^{5}$ Pedagang kaki lima di Jalan Letjen Haryono, Kec. Telanaipura tepatnya di Kantor Inspektorat Provinsi Jambi ditertibkan Satpol PP Provinsi. Tidak hanya sekali Satpol PP memberikan teguran kepada PKL. Apabila teguran tersebut tidak di pindahkan maka Satuan Polisi Pamong Prajaakan menyita barang dagangan. Satuan Polisi Pamong Praja secara bertahap melakukan pendekatan, pertama pendekatan persausif dan membuat surat imbauan. Kedepan, sepanjang Jalan Letjen Haryono akan disterilkan dari para PKL pada saat jam Kerja, dan di perbolehkan berjualan kembali pada jam pulang kerja dan pada malam hari dengan menjaga kebersihan. Pada hari libur PKL yang berjualan masih dipertimbangkan. ${ }^{6}$ Menjaga ketertiban dan keamanan masyarakat merupakan tugas dari Satpol PP yang dibantu oleh Humas Satpol PP dalam penyampaiannya.

Jumlah pedagang kaki lima yang berjualan di sepanjang jalan Inspektorat Dewan Perwakilan Rakyat Daerah Provinsi Letjen M.T Haryono Kec. Telanaipura Provinsi Jambi berjumlah 15 pedagang yang aktif berjualan, mereka berjualan setiap hari. Dalam hal ini perlu adanya strategi komunikasi dalam menjaga ketertiban pedagang kaki lima tujuan ialah agar pedagang kaki lima berjualan sesuai dengan ketentuan pemerintah. Humas Satpol PP penting melakukan

${ }^{4}$ Resty Pratiska, "Peran Satuan Polisi Pamong Praja Dalam Menjaga Ketertiban Umum Dan Ketentraman Mayarakat diakses melalui alamat: https://text.id123dok.com/peran-satuan-polisipamong-praja-dalam-menjga-ketertiban-dan-ketentraman-masyarakat, tanggal 18 Januari 2018.

"Mal," PKL Telanaipura di gusur Satpol PP" diakses melalui alamat: https://halojambi.id/2017/02/pkl-telanaipura-di-gusur-oleh-satpol-pp, Tanggal 18 Januari 2018 
strategi menjaga ketertiban pedagang kaki lima dengan menggunakan komunikasi dalam menjalankan tugasnya. ${ }^{7}$

Pokok masalah penelitian ini adalah bagaimana Strategi komunikasi humas Satuan Polisi Pamong Praja (Satpol PP) Provinsi Jambi menjaga ketertiban di sepanjang Jalan Inspektorat DPRD (Dewan Perwakilan Rakyat Daerah) Provinsi Letjen M.T.Haryono No 2, Kecamatan Telanaipura Provinsi Jambi.

Metode Penelitian yang digunakan dalam penelitian ini adalah peneliti menggunakan metode penelitian yang bersifat Deskriptif. Objek dalam penelitian ini adalah:

1) Kepala Satuan Polisi Pamong Praja, Kantor Satpol PP dan Pemadam Kebakaran Provisi Jambi

2) Sub. Bagian Umum dan Kepegawaian

3) Seksi Ketertiban Umum

4) Humas Satuan Polisi Pamong Praja

5) Pedagang kaki lima

\section{B. Strategi Komunikasi Pedagang Kaki Lima dengan Satuan Polisi Pamong Praja}

Strategi komunikasi hendaknya mencakup segala sesuatu yang dibutuhkan untuk mengetahui bagaimana berkomunikasi dengan khalayak sasaran. Strategi komunikasi mendefinisikan khalayak sasaran, berbagai tindakan yang dilakukan, bagaimana khalayak sasaran akan memperoleh manfaat berdasarkan sudut pandangnya, dan khalayak sasaran yang dapat di jangkau secara efektif. ${ }^{8}$

Strategi merupakan simpulan taktik dalam keperluan bagaimana tujuan yang diinginkan dapat diperoleh atau didapat, oleh sebab itu strategi biasanya terdiri atas dua atau satu taktik, dengan anggapan satu yang lebih bagus dari yang lain

\footnotetext{
${ }^{7}$ Ramli, Satuan polisi Pamong Praja Provinsi Jambi wawancara dengan penulis 12 Maret 2018, Provinsi Jambi, Data Tertulis.

${ }^{8}$ Onong Uchjana Effendi, Ilmu Komunikasi Teori Dan Praktek, (Bandung: Remaja Rosadakarya, 2013), 35
} 
dengan demikian strategi merupakan kumpulan taktik dengan maksud mencapai tujuan dari perusahaan, instansi atau badan. ${ }^{9}$

Tujuan sentral strategi komunikasi terdiri atas tiga tujuan utama, yaitu: a) to secure understanding, b) to establish ecceptance, c) to motivate actions. Pertama adalah (secure understanding) memastikan bahwa komunikan mengerti pesan yang diterimanya. Andaikata sudah mengerti dan menerima, maka penerimaan itu harus dibina (to establish ecceptance). Pada akhirnya kegiatan di motivasikan (to motivate action). ${ }^{10}$

Pada dasarnya, humas (hubungan masyarakat) merupakan bidang atau fungsi tertentu yang diperlukan disetiap organisasi, baik itu organisasi yang bersifat komersial (perusahaan) maupun organisasi yang non komersial. Mulai dari yayasan, perguruan tinggi, dinas militer, sampai dengan lembaga-lembaga pemerintah, bahkan pesantrendan usaha bersamaseperti Gerakan Nasional Orang Tua Asuh (GN-OTA) pun memerlukan Humas. Kebutuhan akan kehadirannya tidak bisa dicegah, terlepas dari itu kita menyukai atau tidak, karena humas memerlukan salah satu elemen yang menentukan kelangsungan suatu organisasi secara positif. Arti penting humas sebagai sumber informasi terpercaya kian terasa pada era globalisasidan "banjir informasi" seperti saat ini. Menurut definisi kamus terbitan Institut of Public Relations (IPR) yakni sebagai sebuah lembaga terkemuka di Inggris dan Eropa, terbitan bulan november 1987," humas adalah keseluruhan upaya yang dilangsungkan secara terencana dalam rangka menciptakan dan memelihara niat baik dan saling pengertian antara suatu organisasi dan segenap khalayaknya". Jadi humas adalah suatu rangkaian kegiatan yang diorganisasi sedemikian rupa sebagai suatu rangkaian kampaye atau program terpadu, dan semua itu dilakukan secara berkesinambungan dan teratur. Kegiatan humas sama sekali tidak bisa dilakukan sembarangan atau dadakan. Tujuan humas itu sendiri adalah untuk bahwa niat

\footnotetext{
${ }^{9}$ Prisgunanto Ilham, Komunikasi Pemasaran Strategi dan Taktik (Jakarta: Ghalia Indonesia 2006), 86

${ }^{10}$ Prisgunanto, Ilham, Komunikasi Pemasaran..., 32
} 
baik dan kiprah organisasi yang bersangkutan senantiasa dimengerti oleh pihakpihak yang berkepentingan(atau lazim disebut seluruh "khalayak" atau publiknya).

Hubungan masyarakat disebut juga Public Relations (Purel) dengan ruang lingkup (scope) kegiatan yang menyangkut baik indivindu ke dalam maupun indivindu keluar dan semua kegiatan diselenggarakan dalam rangka pelaksanaan tugas dan fungsi masing-masing lembaga atau organisasi. Tujuan Humas ialah mengembangkan hubungan yang harmonis dengan pihak lain yakni publik (umum, masyarakat). tujuan Humas adalah untuk menciptakan, membina dan memelihara sikap budi yang menyenangkan bagi lembaga atau organisasi di satu pihak atau dengan publik di lain pihak dengan komunikasi yang harmonis dan timbal balik. ${ }^{11}$

Humas berfungsi untuk mengetahui dan mengevaluasi opini-opini publik yang berkaitan dengan organisasi, serta memanfaatkan komunikasi sebagai media untuk memberikan informasi sesuai dengan fakta, disampaikan dengan cara-cara yang baik dan benar untuk mengarahkan opini publik ke arah yang diharapkan. ${ }^{12}$ Dalam sebuah instansi atau organisasi biasanya mempunyai seorang humas yang menjalankan suatu tugas-tugas yang berhubungan dengan instansi tersebut. Adapun ruang lingkup tugas PR dalam sebuah instansi atau lembaga antara lain:

\section{Membina hubungan kedalam}

Yang dimaksud publik internal adalah Publik yang menjadi bagian dari unit/badan/perusahaan atau organisasi itu sendiri. Seorang PR harus mampu mengindentifikasi atau mengenali hal-hal yang menimbulkan gambaran negatif didalam masyarakat, sebelum kebijakan itu dijalankan oleh organisasi.

\footnotetext{
${ }^{11}$ Widjaja, Komunikasi dan Hubungan masyarakat,(Jakarta: PT.Bumi Aksara,2008),55

${ }^{12}$ Kanal, "Peran Humas (Hubungan Masyarakat) dalam Organisasi", diakses melalui alamat https://www.kanal.web.Id/2016/09 peran-Humas-dalam-organisasi.html tanggal 02 Desember 2017.
} 
2. Membina hubungan ke luar (Publik External)

Yang dimaksud publik eksternal adalah publik umum (masyarakat). mengusahakan tumbuhnya sikap dan gambaran Publik yng positif terhadap lembaga yang diwakilinya. ${ }^{13}$ Dari ruang lingkup di atas Humas menjalin hubungan baik dengan Publik internal dan publik eksternal untuk menciptakan suasana keakaraban diantara keduanya.

Setiap instansi maupun lembaga dalam penyampaian informasi dibantu oleh humas dalam penyampaiannya, sama halnya dengan Kantor Satuan Polisi Pamong Praja Provinsi Jambi dalam penyampaian informasi dibantu oleh humas. Humas merupakan suatu hal yang tidak asing lagi, karena peran dan fungsinya yang sangat penting bagi suatu lembaga, instansi maupun perusahaan, humas adalah bagian dari kegiatan manajemen yang dilakukan secara berkesinambungan oleh organisasi/lembaga/perusahaan untuk memelihara citraserta membentuk opini yang positif dari masyarakat serta khalayak (public) baik internal maupun eksternal. ${ }^{14}$ Satuan Polisi Pamong Praja disingkat Satpol PP adalah perangkat Pemerintah Daerah yang bertugas untuk memelihara ketentraman dan ketertiban umum serta menegakkan peraturan Daerah. organisasi dan tata kerja Satuan Polisi Pamong Praja ditetapkan oleh peraturan Daerah, Satpol PP dapat berkedudukan di Daerah atau Provinsi, Satuan Polisi Pamong Praja dipimpin oleh kepala yang berada dibawah dan bertanggung Jawab kepada Gubernurmelalui Seketaris Daerah. di Daerah Kabupaten/Kota, Satuan Polisi Pamong Praja di pimpin oleh kepala yang berada dibawah dan bertanggung jawab kepada Bupati/Walikota melaui Seketaris Daerah. ${ }^{15}$

\footnotetext{
${ }^{13}$ Rusady Ruslan, Manajemen Public Relations dan media Komunikasi, (Jakarta: Rajawali Pers, 2012), 22-23

${ }^{14}$ May Rudi, Komunikasi dan Hubungan Masyarakat Internasional (Bandung: Angkasa,2005), 9

${ }^{15}$ Shofal Jamil,” Asal-usul Sejarah Terbentuknya Satuan Pamong " diakses melalui alamat: http://asalusulshofaljamil.com/2010/04/asal-usul-sejarah-terbentuknya-satuan- pamong.html tanggal 16 Agustus 2018
} 
Istilah komunikasi atau dalam bahasa inggriscommunications berasal dari kata latin communicatio, bersumber dari kata communis yang berarti sama. Sama disini maksudnya sama makna. Jadi, kalau orang yang yang terlibat dalam komunikasi, misalnya dalam bentuk percakapan, maka komunikasi akan terjadi dan berlangsung selama ada kesamaan makna mengenai apa yang dipercakapkan.

a. Bentuk-bentuk Komunikasi

1) Komunikasi Persuasif: Terkadang kepercayaan seseorang tentang sesuatu yang dipercayainya dapat memberikan dampak sikap pada mereka.Sehingga dapat mempengaruhi prilaku dan tindakan mereka terhadap sesuatu. Dengan kata lain mengubah pengetahuan seseorang tentang sesuatu yang dipercayainya dapat merubah prilaku mereka. ${ }^{16}$

2) Komunikasi Surat: Surat merupakan sarana komunikasi tertulis untuk menyampaikan informasi, pernyataan atau pesan kepada pihak lain yang mempunyai keperluan kegiatan dengan bentuk tertentu. Dengan demikian surat membawa informasi, peryataan atau pesan yang diharapkan informasi itu akan tersampaikan kepada yang dituju kepada penulis surat.

Apabila ditunjau dari sifatnya, surat adalah jenis karangan paparan, sebab pengirim surat mengemukakan maksud dan tujuannya, menjelaskan apa yang difikirkannya dan dirasakannya melalui surat. Berbeda halnya jika ditinjau dari wujud penuturannya, surat merupakan percakapan tertulis dari seseorang kepada seseorang atau dari lembaga ke lembaga. ${ }^{17}$

3) Komunikasi melalui sosialisasi

Komunikasi merupakan elemen penting bagi proses sosialisasi bagi masyarakat. Karena tanpa adanya komunikasi antar anggota masyarakat,

\footnotetext{
${ }^{16}$ PakarKomunikasi,"Komunikasi Persuasif pengertian bentuk dan Tujuan”, diakses melalui alamat: https://pakarkomunikasi.com/2017/03/komunikasi-persuasif- pengertian-bentuk-dantujuan. tanggal 05 Juni 2018

${ }^{17}$ Arifiens, "Pengertian dan Fungsi Surat", diakses melalui alamat: arifiens.blogspot/2010/11/pengertian- dan-fungsi-surat tanggal 05 Juni 2018
} 
proses sosialisasi tidak akan dapat berlangsung. Jadi dengan adanya komunkiasi proses sosialisasi dalam masyarakat akan dapat berlangsung secara maksimal. Jadi komunikasi mendukung dan menjadi faktor utama terjadinya suatu sosialisasi di dalam masyarakat tidak akan berlangsung atau tercipta dengan baik. ${ }^{18}$

a. Proses komunikasi : Proses komunikasi di bagi menjadi dua tahap, yaitu:

1) Proses komunikasi secara primer : Proses komunikasi secara primer adalah proses penyampaian pemikiran atau perasaan seseorang kepada orang lain dengan menggunakan lambang (simbol) sebagai media. Lambang sebagai media primer dalam proses komunikasi adalah bahasa, kial, isyarat, gambar, warna dan lain sebagainya yang secara langsung menerjemahkan pikiran atau perasaan kepada komunikan. Bahwa bahasa yang paling banyak digunakan dalam komunikasi adalah jelas karena hanya bahasalah yang mampu menerjemahkan pikiran seseorang kepada orang lain.

2) Proses komunikasi secara sekunder : Proses komunikasi secara sekunder adalah proses penyampaian pesan seseorang kepada orang lain dengan menggunakan alat atau sarana sebagai media kedua setelah memakai lambang. Seseorang komunikator menggunakan media kedua dalam melancarkan komunikasinya karena komunikan sebagai sasarannya berada di tempat relatif jauh atau jumlahnya banyak. Surat, telepon, teleks, surat kabar, majalah, radio televisi, film, dan banyak lagi adalah media kedua yang sering digunakan dalam komunikasi. ${ }^{19}$

a. Unsur-unsur komunikasi

1) Sumber: Semua peristiwa komunikasi akan melibatkan sumber sebagai pembuat atau pengiri informasi dalam komunikasi antar manusia, sumber

\footnotetext{
${ }^{18}$ Garry Cantona," Keterkaitan Komunikasi dan Sosialisasi di Masyarakat”, diakses melalui alamat:penjajahpantai.blogspot.com/2011/12/keterkaitan-komunikasi-dan-sosialisasi-dimasyarakat 05 Juni 2018

${ }^{19}$ Onong Uchjana Effendy, Ilmu Komunikasi Teori dan Praktek, (Bandung: PT.Remaja Rosdakarya, 2013) 9-16
} 
bisa terdiri dari satu orang, tetapi bisa juga dalam bentuk kelompok misalnya: partai, organisasi atau lembaga.

2) Pesan : Pesan yang dimaksud dalam proses komunikasi adalah sesuatu yang disampaikan pengirim kepada penerima. Pesan dapat disampaikan dengan cara tatap muka atau dengan menggunakan media komunikasi.

3) Media: Media yang dimaksud disini adalah alat yang digunakan utuk memindahkan pesan dari sumber ke penerima. Terdapat beberapa pendapat mengenai saluran atau media. Ada yang menilai bahwa media bisa bermacam-macam bentuknya, misalnya dalam komunikasi antar pribadi panca indra dianggap sebagai media komunikasi. Selain indra manusia ada juga saluran komunikasi seperti telepon, surat, telegram, yang di golongkan sebagai media komunikasi antarpribadi.

4) Penerima: Penerima adalah pihak yang menjadi sasaran pesan yang dikirim oleh sumber. Penerima bisa terdiri dari satu orang atau lebih bisa dalam bentuk kelompok, partai, atau negara.

5) Tanggapan balik: Ada yang beranggapan bahwa umpan balik sebenarnya adalah salah satu bentuk dari pengaruh yang berasal dari penerima.

6) Lingkungan: Lingkungan atau situasi ialah faktor-faktor tertentu yang dapat mempengaruhi jalannya komunikasi. ${ }^{20}$

a. Humas sebagai Kegiatan Komunikasi

Kegiatan komunikasi selalu terjadi dalam kehidupan sehari-hari, terutama dalam kehidupan PR (Pulic Relations). Pulic Relations/PR dalam melaksanakan fungsi dan kegiatannya berpusat pada komunikai secara langsung maupun tidak langsung, verbal maupun non verbal dengan bentuk apapun. Komunikasi yang efektif kepada karyawan, pelanggan, pemegang saham, masyarakat di sekitar perusahaan dan publik lainya adalah esensial bagi PR yang baik. $22-28$

${ }^{20}$ Hafied Cangara, Pengantar Ilmu Komunikasi, (Jakarta: PT.Raja Grafindo Persada, 2007), 
Hubungan dengan masyarakat hanya bisa dibina dengan berkomunikasi dengan mereka. Kalau komunikasi berkurang, maka kesalapahaman dan pertentangan akan terjadi. Rintangan dalam mencapai keberhasilan untuk menyatukan pikiran diantara orang-orang dalam indudtri, perburuhan, industri dan komuniktas dan pemerintah harus diatasi dengan komunikasi yang lebih efektif.

Komunikasi Humas/PR merupakan proses yang mencakup suatu pertukaran fakta, padangan dan gagasan diantara suatu bisnis atau organisasi tanpa laba dengan publik-publiknya untuk mencapai saling pengertian. Ada tiga butir yang perlu dipertimbangkan: pertama, komunikasi melibatkan dua orang atau lebih; kedua komunikasi merupakan pertukaran informasi yang bersifat dua arah; ketiga mengandung pemahaman. ${ }^{21}$

\section{b. Pedagang Kaki Lima}

Tugas penting eksternal Public Relations/Humas mengadakan komunikasi yang efektif, yang bersifat informatif dan persuasif, yang di tujukan kepada publik di luar instansi tersebut. Informasi harus diberikan jujur, berdasarkan fakta yang harus diteliti. Sebab public mempunyai hak untuk mengetahui keadaan yang sebenarnya tentang sesuatu yang menyangkut kepentingannya. Setiap instansi maupun organisasi dalam penyampaian pesan baik internal maupun eksternal memelukan humas dalam penyampaiannya. ${ }^{22}$

Humas Kantor Satuan Polisi Pamong Praja Provinsi Jambi bertugas menyampaikan pesan baik internal maupun eksternal. Pesan atau informasi ekternal ditujukan kepada Pedagang kaki lima yang berjualan di jalan inspektorat DPRD Provinsi M.T Haryono Kecamatan Telanaipura Provinsi Jambi untuk menjaga ketertiban dalam berdagang. Terdapat 15 pedagang kaki lima

\footnotetext{
${ }^{21}$ Moore Frazier, Humas Membangun Citra, Membangun Citra dengan Organisasi,(Bandung: PT.Rosdakarya2005), 86

${ }^{22}$ Scott M.Cultip, Effective Public Relations, (Jakarta: Prenada Media Grup, 2006), 40
} 
yang aktif berjualan setiap hari dikawasan tersebut. Dalam hal ini perlu adanya strategi untuk menjaga ketertiban.

Menurut Kamus Bahasa Indonesia maka istilah kaki lima mempunyai arti lantai (tangga) dimuka pintu atau di tepi jalan" dan "lantai diberi beratap sebagai penghubung rumah dengan rumah. Pengertian tersebut mirip dengan trotoar yang luasnya lima kaki 1,5 meter yang dibuat dimasa penjajahan (Belanda atau Inggris). Namun, pengertian yang dimaksudkan kamus itu juga bisa diartikan emperan toko. Karenanya selain trotoar, PKL juga berjualan di emperan toko. Ada juga membuat istilah lain kaki lima diartikan "kanan, kiri lintas manusia" maksudnya barangkali karena PKL berada dijalur pejalan kaki (trotoar dan emperan toko), sehingga banyak yang barlalu-lalang di samping kanan dan samping kiri PKL. ${ }^{23}$ Jadi pengertian Pedagang Kaki lima adalah orang yang berjualan di tempat atau di tepi jalan yang lebarnya (5 feet). Tempat ini umumnya terletak di trotoar, depan toko atau tepi jalan. ${ }^{24}$ Dalam Hal ini Humas Satuan Polisi Pamong Praja melakukan strategi komunikasi guna menjaga ketertiban pedagang kaki lima dalam proses berdagang agar sesuai dengan peraturan yang telah ditetapkan.

\section{Profil Satuan Polisi Pamong Praja Jambi}

Pada saat awal masa kemerdekaan namanya adalah Polisi Pamong Praja. Polisi Pamong Praja didirikan di Yogyakarta pada tanggal 3 maret 1950 moto praja wibawa untuk mewadahi sebagian ketugasan pemerintah daerah. Sebelum menjadi Satuan Polisi Pamong Praja Setelah Proklamasi kemerdekaan dimana diawali dengan kndisi tidak stabil dan mengancam NKRI, dibentuklah Detasemen Polisi sebagai penjaga keamanan Kapanewon di Yogyakarta untuk menjaga

\footnotetext{
${ }^{23}$ Gilang Permadi, Pedagang Kaki Lima Riwayatmu Dulu Nasibmu Kini, (Indonesia: Yudhistira Ghalia: 2007), 4

${ }^{24}$ Joxyt, "Pengertian Pedagang Kaki Lima" diakses melalui alamat: https://joxyt.blogspot.com./2013/09/pengerttian-pedagang-kaki-lima tanggal $21 \quad$ Januari 2018
} 
ketentraman dan ketertiban masyarakat. Jawa dan Madura Satuan Polisi Pamong Praja dibentuk tanggal 3 Maret 1950 inilah awal mula dibetuknya Satpol PP. Dan oleh sebab itu, karena meningkatnya jumlah pertumbuhan penduduk dan peta rawan ketertiban kawasan pemukiman penduduk hal ini mengakibatkan perlu adanya pengaturan yang baik dari sisi pemerintah untuk dapat mengantisipasi segala macam tantangan yang bermuara pada terancamnya ketertiban umum dan ketentraman masyarakat. Menteri Dalam Negeri pada tanggal 3 Maret 1950 mengeluarkan Surat Keputusan Nomor UR 32/2/21 tentang perubahan nama Detasemen Polisi Pamong Praja menjadi Satuan Polisi Pamong Praja dan setiap tanggal 3 Maret ditetapkan sebagai Hari Jadi Satuan Polisi Pamong Praja (Satpol PP). ${ }^{25}$ Satuan Polisi Pamong Praja Provinsi Jambi mempunyai tugas dan kewajiban adalah: membantu Gubernur dalam rangka memelihara dan menyelenggarakan ketentraman dan ketertiban umum serta menegakan Peraturan Daerah, Peraturan Kepala Daerah dan Keputusan Gubernur. ${ }^{26}$

Kantor Satuan polisi Praja Provinsi jambi yang bertempat di Jalan Ahmad Yani No 10 Kecamatan Telanaipura Provinsi Jambi.Kantor Satuan Polisi Pamong Praja didirikan Tahun 2000 di bawah biroPemerintahan. Dimulai sejak Kantor Satuan Polisi Pamong Praja di dirikan humas mulai dibentuk.Tujuan Humas dibentuk pada saat itu adalah untuk membantu Satuan Polisi Pamong Praja dalam komunikasi dua arah.Komunikasi dua arah tersebut adalah komunikasi internal (dalam instansi) dan komunikasi ekternal (luar instansi).

Pada Tahun 2016 Kantor Satuan Polisi Pamong Praja bergabung dengan Kantor Pemadam Kebakaran hingga saat ini.penggabungan kantor Satuan Polisi Pamong Praja dengan Pemadam Kebakaran adalah untuk membatu Pemadam Kebakaran dalam pengendalian dan pencegahan bencana. Struktur organisasi

\footnotetext{
${ }^{25}$ Tim Penyusun. Buku II: Media Praja Wibawa Jaya (Informasi Penegakan Peraturan Daerah, (Jambi: Satuan Polisi Pamong Praja Provinsi Jambi, 2015), 62.

${ }^{26}$ Ronal Saputra, " Daftar Alamat Tugas dan Fungsi Kantor Pemerintahan Provinsi Jambi" diakses melalui alamat: ronalsaputraa.blogspot.com/2014/02/daftar-alamat-tugas-dan-fungsikantor-pemerintahan-provinsi-jambi.com, tanggal 20 Agustus 2018.
} 
Kepemimpinan Satuan Polisi Pamong Praja dan Pemadam Kebakaran dipimpin oleh Satu Kepala Satuan dimulai dari 2016 sampai sekarang.

Hasil wawancara penulis dengan bapak Yosse Martasudira sebagai Kasubag Umum dan kepegawaian di Kantor Satuan Polisi Pamong Praja dan Pemadam Kebakaran, menyatakan"[D]ulu Pol PP ini dibawah Biro Pemerintahan Tahun 2000 Kantornyo Pol PP be Pada Tahun 2016 Pol PP dan Damkar Kantornyo bergabung alasanyo tu untuk pengendalian pencegahan bencana dan dipimpin oleh satu Kasat". ${ }^{27}$

Dari hasil wawancara penulis dengan bapak Yosse Martasudira diatas dapat disimpulkan bahwa sejarah Kantor Satuan Polisi Pamong Praja di bawah biro pemerintahan dan sejarah belum dibukukan, karena penulis mendapat sejarah hanya lewat wawancara saja, bukan dengan dokumen.

\section{Strategi Komunikasi Humas Satuan Polisi Pamong Praja Jambi}

\section{Komunikasi Melalui Surat}

Perkembangan teknologi komunikasi dan informasi demikian pesat, komunikasi melalui surat menyurat dalam lembaga/instansi masih memegang peranan penting komunikasi melalui surat biasanya berkaitan dengan penyampaian informasi lembaga instansi yang ditujukan baik secara internal maupun eksternal. Komunikasi melalui surat biasanya berupa pengumuman, pemberitahuan, keterangan, dan sebagainya. ${ }^{28}$

Setiap instansi atau organisai Humas sangat dibutuhkan dalam penyampaian pesan. Humas sebagai suatu kegiatan atau usaha yang berencana

\footnotetext{
${ }^{27}$ Yosse Martasudira, Kasubag Umum dan Kepegawaian Satuan Polisi Pamong Praja dan Pemadam Kebakaran, Wawancara dengan Penulis, 14 Mei 2018, Provinsi Jambi, Rekaman Audio.

${ }^{28}$ Arifiens," Pengertian dan Fungsi Surat", diakses melalui alamat: http://ariefiens.blogspot.com/2010/11/pengertian-dan-fungsi-surat.com tanggal 19 Agustus 2018
} 
yang menyangkut i'tikad baik, rasa simpati, saling mengerti dan memperoleh pengakuan, penerimaan, dan dukungan masyarakat melalui komunikasi dan sarana lain (media massa) untuk mencapai kemanfaatan dan kesepakatan bersama. ${ }^{29}$ Surat merupakan salah satu bentuk komunikasi yang sering digunakan. instansi atau organisasi memerlukan humas karena humas merupakan usaha-usaha yang bertujuan untuk menciptakan komunikasi atau hubungan yang baik antara satu instansi dengan publiknya, baik internal maupun eksternal agar memperoleh pengertian yang sama.

\section{Komunikasi Melalui Sosialisasi}

Sosialisasi merupakan sebuah proses paling penting yang secara sadar atau tidak sering kita jalani setiap harinya. Sosialisasi itu sendiri dapat diartikan sebuah proses pengenalan nilai-nilai yang sedemikian rupa hingga akhirnya terbentuk suatu indivindu yang utuh. Maka dapat dikatakan apabila seseorang indivindu tidak pernah melakukan sosialisai dengan sempurna, ia dapat diibaratkan sebagai seseorang indivindu yang tidak utuh. ${ }^{30}$

Humas bertanggung jawab mengkomunikasikan berbagai kebijakan dan tindakan instansi kepada publik, baik internal maupun eksternal.Komunikasi yang dibangun harus dua arah.Tujuannya untuk menciptakan saluran informasi sehingga tidak ada aspirasi atau harapan dari dua pihak yang terhambat. ${ }^{31}$

${ }^{29}$ Morissan, Manajemen Public Relations Strategi Menjadi Humas Profesional, (Jakarta: Perdana Media Group, 2008), 8

${ }^{30}$ Kamanto dan Sunarto, Pengantar Sosiologi (Edisi Revisi), (Jakarta: Lembaga Penerbit Fakultas Ekonomi Universitas Indonesia, 2004), 19.

${ }^{31}$ Inca Rahel Lalihatu "Hubungan Humas dengan Sosialisasi" diakses Melalui Alamat: https://media.neliti.com/media/publicrelations/177488-ID-peranan-humas - dan humas dalam-mensosialisasikan- bp.pdf, tanggal 10 Juni 2018 


\section{Penutup}

Dari hasil penelitian tentang Strategi Komunikasi Humas Satuan Polisi Pamong Praja Provinsi Jambi Menjaga Ketertiban Pedagang Kaki Lima dapat diambil dari beberapa kesimpulan sebagai berikut:

1. Srategi Komunikasi Humas Satuan Polisi Pamong Praja menjaga ketertiban pedagang kaki lima: Komunikasi persuasif, komunikasi melalui surat, komuniaksi melalui sosialisasi.

2. Dampak Strategi Komunikasi Humas Satuan Polisi Pamong Praja Provinsi Jambi Menjaga Ketertiban Pedagang Kaki Lima untuk saat ini mengalami kemajuan yang baik. Walaupun demikian Tetapi ada pedagang kaki lima yang melanggar peraturan yang telah ditetapkan, yaitu masih ada pedagang yang sebelum jam kerja/kantor berakhir pada pukul 16.00 WIB ada yang berjualan. Tetapi sejauh ini bisa dikendalikan dengan memanggil pedagang tersebut ke Kantor Satuan Polisi Pamong Praja Provinsi Jambi untuk memberikan keterangan. Humas Satuan Polisi Pamong Praja memberikan arahan kepada pedagang tersebut untuk bisa menaanti peraturan yang ditetapkan.

\section{Daftar Pustaka}

Anggoro, M.Linggar Teori dan Profesi Kehumasan Serta Aplikasinya, Jakarta:Bumi Aksara,2000

Arikunto, Suharsimi Prosedur Penelitian Suatu Pendekatan Praltis, Jakarta: Rineka Cipta,1997

Cangara Hafied, Pengantar IImu Komunikasi, Jakarta: Raja Grafindo Persada, 2007

Gilang, Permadi Pedagang Kaki Lima Riwayatmu Dulu Nasibmu Kini, Indonesia: Yudhistira Ghalia: 2007

Hadi, Sutrisno Metode Research, Yogyakarta:Gramedia,1990 
Hamidi, Metode Penelitian Kualitatif Aplikasi Praktis Pembuatan Proposal dan Laporan Penelitian, Malang: UMM Press, 2004

Ilahi, Wahyu Komunikasi Dakwah, Bandung: Remaja Rosdakarya, 2010

Lexy Moleong, Metode Penelitan Kualitatif ,Bandung: Remaja Rosdakarya, 2011

M.Cultip, Scott Effective Public Relations, Jakarta: Prenada Media Grup, 2006

Malik, Djamaludin et. Al., Komunikasi Persuasive Bandung: Remaja Rosdakarya, 1994

Moore, Frazier Humas Membangun Citra dengan Organisasi, Bandung: Rosdakarya 2005

Morissan, Manajemen Public Relations Strategi Menjadi Humas Profesional, Jakarta: Perdana Media Group, 2008

Mulyana, Deddy Ilmu Komunikasi Suatu Pengantar, Bandung: Remaja Rosdakarya, 2002

Rudi, May, Komunikasi dan Hubungan Masyarakat Internasional, Bandung: Angkasa, 2005

Ruslan, Rosady Manajeman Public Relations dan Media Komunikasi, Jakarta: Raja Grafindo Persada ,2008

Suharsimi Arikunto, Prosedur Penelitian Suatu Pendekatan Praltis, Jakarta: Rineka Cipta,1997

Sugiyono, Metode Penelitian kuantitatif kualitatif, Dan R\&D, Bandung: Alfabeta,2010

Sunarto, Kamanto Pengantar Sosiologi (Edisi Revisi), Jakarta: Lembaga Penerbit Fakultas Ekonomi Universitas Indonesia, 2004

Suryanto, Pengantar Ilmu Komunikasi, Bandung: Pustaka Setia, 2015

Peraturan Gubernur Jambi, Kedudukan Susunan Organisasi Tugas dan Fungsi Serta Tata kerja Satuan Polisi Pamong Praja Provinsi Jambi, Nomor 30 Tahun 2016 
Prastowo, Andi Metode Penelitian Kualitatif dalam Prespektif Rancangan Penelitian, Yogyakarta:Alfabeta,2007

P Siagian, Sondang, Filsafat Administrasi, Jakarta: Rineka Cipta, 1997

Uchjana Onong Effendy, IImu Komunikasi Teori dan Praktek, Bandung: PT.Remaja Rosdakarya, 2013

Widjaja,Komunikasi dan Hubungan Masyarakat,Jakarta: Bumi Aksara,2008

Walgito Bimo, Psikologi Sosial, Yogyakarta: CV.Andi Offset ,2003

Tim Penyusun. Buku,Panduan Penulisan Karya Ilmiah ,(Jambi: Fak.Ushulluddin IAIN Jambi, 2006

Tim Penyusun. Buku II: Media Praja Wibawa Jaya Informasi Penegakan Peraturan Daerah, Jambi: Satuan Polisi Pamong Praja Provinsi Jambi, 2015

Mulyana, Deddy Ilmu Komunikasi Suatu Pengantar, Bandung: Remaja Rosdakarya, 2002

Eka Novianti Pratiwi, "Wewenang Satuan Polisi Pamong Praja (Satpol PP) Dalam Penegakkan Peraturan Daerah Di Kota Makassar". PDF Repository.Unhas.ac.id (2014), (diunduh 19 Desember 2017)

Fredi Anton Saputro, dengan judul "Peranan Satuan Polisi Pamong Praja Dalam Mengimplemantasikan Peraturan Daerah Tentang Pedagang Kaki Lima Di Surakarta".PDF lip.unnes.ac.id(2013), (diunduh 19 Desember 2017)

Eva Setiawati, Peran Humas Dalam Menyebarkan Informasi (Studi Kasus Pemadaman Listrik PT.PLN Rayon Jambi Kec. Sungai Gelam) Jambi:Skripsi Studi Kasus Konsesntrasi Public Relations Fakultas Ushuluddin.2017

Soimah, Peran Humas Satuan Polisi Pamong Praja (Satpol PP) Provinsi Jambi dalam Membangun Citra Positif di Masyarakat., Jambi: Skripsi Studi Kasus Kosentrasi Public RelationsFakultas Ushuluddin, 2015 
Conita, Fetty, "Tujuan dan Fungsi Humas", diakses melalui alamat: onyet.note.fisip.uns.ac.id/2016/06/ tujuan - dan - fungsi -humas.id Tanggal 20 Juli 2018

Cantona, Gari." Keterkaitan Komunikasi dan Sosialisasi di Masyarakat", diakses melalui alamat: penjajah pantai. blogspot. com/2011/12/ keterkaitan-komunikasidan-sosialisasi-di-masyarakat, Tanggal 05 Juni 2018

Joxyt, "Pengertian Pedagang Kaki Lima" diakses melalui alamat: https:// joxyt.blogspot.com./2013/09/pengerttian-pedagang-kaki-lima Tanggal 21 Januari 2018

Kanal, "Peran Humas (Hubungan Masyarakat) dalam Organisasi", diakses melalui alamat: https:// www.kanal.web.ld/2016/09 peran-Humasdalam -organisasi.html Tanggal 02 Desember 2017

Mal," PKL Telanaipura di gusur Satpol PP" diakses melalui alamt: https:// halojambi.id/2017/02/pkl-telanaipura-di-gusur-oleh-satpol-pp Tanggal 18 Januari 2018

Rahel, Icha Lalihatu. "Hubungan Humas dengan Sosialisasi" di Akses MelaluiAlamat:https://media.neliti.com/media/publicrelations/17748 8IDperanan -humas-dalam-mensosialisasikan-bp.pdf, Tanggal 10 Juni 2018,

Pratiska, Resty. "Peran Satuan Polisi Pamong Praja Dalam Menjaga Ketertiban Umum Dan Ketentraman Mayarakat diakses melalui alamat: https://text.id123dok.com/peran-satuan-polisi-pamong-prajadalam menjaga-ketertiban-dan-ketentraman-masyarakat, Tanggal 18 Januari 2018

Kanal, "Peran Humas (Hubungan Masyarakat) dalam Organisasi", diakses melalui alamat: https:// www.kanal.web.ld/2016/09 peran-Humasdalam -organisasi.html Tanggal 02 Desember 2017. 
Peraturan Pemerintah Pasal 4 No 18 Tahun 2016, diakses melalui alamat: https//database.peraturanpemerintah.com/2016/06/peraturanpemerintah-pasal-4-no-18-tahun-2016.com tanggal 23 Agustus 2018 Ronal Saputra, "Daftar Alamat Tugas dan Fungsi Kantor Pemerintahan Provinsi Jambi" diakses melalui alamat: ronalsaputraa.blogspot.com/2014/02/daftar-alamat-tugas-dan-fungsikantor - pemerintahan-provinsi-jambi.com, tanggal 20 Agustus 2018 Public RelationsHumas." Tugas Pokok dan Fungsi Humas" diakses melalui alamat: humas - publicrelations.blogspot.com/2013/10/tugas-pokokdanfungsi-humas.html, tanggal 20 juli 2018

Shofal Jamil," Asal-usul Sejarah Terbentuknya Satuan Pamong " diakses melalui alamat: http://asalusulshofaljamil.com/2010/04/asal-usulsejarah-terbentuknya-satuan-pamong.html Tanggal 16 Agutus 2018

Dokumentasi, Struktur Organisasi di Kantor Satuan Polisi Pamong Praja dan Pemadam Kebakaran Provinsi Jambi, 3 Mei 2018,

Dokumentasi 3 Mei 2018, di Kantor Satuan Polisi Pamong Praja dan Pemadam Kebakaran Provinsi Jambi.

Dokumentasi 3 Mei 2018, di Kantor Satuan Polisi Pamong Praja dan Pemadam Kebakaran Provinsi Jambi. 